\title{
Metabolic Effects of Human Growth Hormone in Corticosteroid-Treated Children
}

\author{
Helen G. Morris, Jacqueline R. Jorgensen, Harold Elrick, and \\ Richard E. Goldsmith, with the technical assistance of Vibart L. Subryan \\ From the Department of Medicine, Veterans Administration Hospital, \\ University of Colorado School of Medicine, and Children's Asthma \\ Research Institute and Hospital, Denver, Colorado; Metabolic \\ Laboratories, Cincinnati General Hospital, Cincinnati, Ohio.
}

A B S T R A C T The effects of administered human growth hormone $(\mathrm{HGH})$ were evaluated in dwarfed, prepubertal children who were receiving long-term corticosteroid therapy for a chronic disease. During 11 complete metabolic balance studies, the eight corticosteroid-treated children demonstrated impaired response to large doses of $\mathrm{HGH}$ with minimal nitrogen and no phosphorus retention. In contrast, two hypopituitary subjects and two asthmatic children not receiving corticosteroid responded to the same preparations of $\mathrm{HGH}$ with nitrogen, potassium, and phosphorus retention. Six corticosteroid-treated children were given large doses of $\mathrm{HGH}(40-120 \mathrm{mg} / \mathrm{wk}$ for 4 to 8 months and showed no improvement in their retarded rate of growth, whereas the hypopituitary subjects showed accelerated growth during administration of $10-15 \mathrm{mg}$ of $\mathrm{HGH} /$ wk. It is concluded that dwarfism in steroid-treated children results from corticosteroid-induced antagonism of the effects of $\mathrm{HGH}$ at the peripheral tissue level.

\section{INTRODUCTION}

One of the more distressing features of long-term corticosteroid therapy of children is the resultant

\footnotetext{
A preliminary report was presented in part in the Proceedings of the Endocrine Society, 47th meeting, 1965. (Abstr. No. 183)

Address requests for reprints to Dr. Helen G. Morris, 1055 Clermont Street, Denver, Colo. 80220.

Received for publication 7 November 1966 and in revised form 21 September 1967.
}

inhibition of growth (1). The present study was undertaken to obtain further information about the relationship of human growth hormone $(\mathrm{HGH})$ to this form of dwarfism. Response to $\mathrm{HGH}$ was evaluated during complete metabolic balance study and during prolonged administration to children who were receiving corticosteroids for a chronic disease and who exhibited growth retardation as a result of corticosteroid therapy $(2-4)$.

\section{METHODS}

Patients. The corticosteroid-treated group consisted of eight children who were 2 or more standard deviations below normal in height. Most of the children showed minimal evidence of Cushing's syndrome other than growth retardation. Prepubertal subjects were selected so that any response to HGH would not be confused with an adolescent growth spurt. Six children were receiving corticosteroids for intractable asthma, one for rheumatoid arthritis, and one for the nephrotic syndrome. The asthmatic subjects were drawn from the patient population of the Children's Asthma Research Institute and Hospital where previous studies have shown that growth retardation is directly attributable to corticosteroid therapy, since steroid-treated children show more severe growth inhibition, despite better control of asthma, than the nonsteroid-treated children $(3,4)$. The metabolic effects of $\mathrm{HGH}$ during 11 studies of the corticosteroidtreated patients were compared with those of two children with panhypopituitarism and two asthmatic children not receiving corticosteroid. The pertinent clinical features are summarized in Table I.

Metabolic balance studies. During a prolonged prestudy observation period, and during both the acute balance and the long-term phases of the study, corticosteroid (prednisone) dosage was maintained at a constant level 
TABLE I

Clinical Data on Subjects for Metabolic Balance Study

\begin{tabular}{|c|c|c|c|c|c|c|}
\hline Patient & Sex & Age & Diagnosis & $\begin{array}{l}\text { Height, deviation } \\
\text { from mean }\end{array}$ & Steroid dose & Fasting HGH \\
\hline & & & & & & $m \mu g / m l$ \\
\hline P. L. & M & 12 & Asthma & $-2.2 \mathrm{sD}$ & Prednisone, $5 m g$ b.i.d. & 8.5 \\
\hline J. O'N. & $\mathbf{M}$ & 12 & Asthma & $-2.6 \mathrm{sD}$ & Prednisone, $5 \mathrm{mg}$ q.i.d. & 14 \\
\hline \multirow[t]{3}{*}{ C. B. } & $\mathrm{F}$ & 12 & Asthma & $-4.4 \mathrm{SD}$ & Study 1 , no steroid & \\
\hline & & & & & Study 2 , prednisone & \\
\hline & & & & & $2.5 \mathrm{mg}$ t.i.d. & 6 \\
\hline J. S. & $\mathbf{M}$ & 12 & Asthma & $-3.7 \mathrm{sD}$ & Prenisone, $2.5 \mathrm{mg}$ t.i.d. & 1.5 \\
\hline M. K. & $\mathrm{F}$ & 12 & Asthma & $-3.4 \mathrm{SD}$ & Prednisone, $5 m g$ b.i.d. & 4.2 \\
\hline K. K. & $\mathbf{M}$ & 13.5 & Asthma & $-4.0 \mathrm{sD}$ & Prednisone, $5 m g$ t.i.d. & $<1$ \\
\hline M. P. & $\mathrm{F}$ & 12 & Rheumatoid arthritis & $-5.5 \mathrm{SD}$ & Prednisone, $5 m g$ t.i.d. & \\
\hline C. W. & $\mathrm{F}$ & 8 & Nephrosis & $-4.0 \mathrm{sD}$ & Prednisone, 5 mg q.i.d. & 10 \\
\hline E. LJ. & $\mathbf{M}$ & 12 & Asthma & $-2.2 \mathrm{sD}$ & None & 5.0 \\
\hline D. H. & $\mathbf{M}$ & 18 & Panhypopituitarism & & None & $<1$ \\
\hline J. M. & $\mathrm{F}$ & 16 & Panhypopituitarism & & None & $<1$ \\
\hline
\end{tabular}

and was the minimum required by each child at the beginning of the study for control of symptoms. Children were hospitalized in the Clinical Research Center of the University of Colorado Medical School for complete metabolic balance studies which were carried out by standard balance techniques. Each study consisted of an 8 day stabilization period, an 8 day pre-HGH control period, 8-12 days of $\mathrm{HGH}$ administration, and an 8 day post-HGH period. Throughout the study, urine was collected in 24-hr pools and stools in 96-hr pools. Children received a constant diet of their choice. Food was eaten under observation of the dietitian, and there were no returns or refusals (except by patient J. M. whose returns were analyzed and during study I by patient C. B. who managed to hide some food). Most of the balance studies were performed on two children simultaneously to provide an additional check on the technical aspects of the study.

$\mathrm{HGH}$ (Elrick) had an activity of $1.0 \mathrm{USP}$ unit/mg $(5,6)$, as demonstrated by rat tibia bioassay. The hormone was dissolved with several drops of $0.1 \mathrm{~N} \mathrm{NaOH}$ and diluted with normal saline; fresh solutions were prepared every $48 \mathrm{hr}$. HGH was administered daily by intramuscular injection in a volume of $1 \mathrm{ml}$ preceded by $0.4 \mathrm{ml}$ of $1 \%$ procaine hydrochloride given through the same needle (7). During the pre-HGH control period, children were given placebo injections of procaine followed by normal saline. HGH dosage for the children with hypopituitarism was $5 \mathrm{mg} /$ day. Preliminary observations suggested that steroid-treated children were unresponsive to $\mathrm{HGH}$ doses of $10 \mathrm{mg} /$ day. Therefore, steroid-treated children received several consecutive 4-day periods of $\mathrm{HGH}$ administration during which the dose was progressively increased from 10 to $30 \mathrm{mg} /$ day in an attempt to achieve a dose of $\mathrm{HGH}$ which would be metabolically effective.

Methods of analysis. Specimens were analyzed for nitrogen by the micro-Kjeldahl method (8), calcium by atomic absorption (9), phosphate by the method of Chen, Toribara, and Warner (10), sodium and potassium by the flame photometer, and chloride and creatinine by the AutoAnalyzer $(11,12)$. For some of the studies (M. P., E. LJ., D. H., J. M.) intake was determined by analysis. In the remaining studies intake was determined by calculation from standard food composition charts $(13,14)$. Studies in our laboratory have indicated excellent agreement between analyzed and calculated diet composition with the exception of phosphorus content where analysis consistently yields slightly higher values than those determined by calculation. 1

Metabolic balance was calculated for each substance and was compared with theoretic balance (15). The results of the balance studies are charted according to the method of Reifenstein, Albright, and Wells (16), with intake plotted down from the zero line and excretion plotted up from the intake line. Positive metabolic balance is indicated by a clear zone below the zero line and negative balance by excretion above the zero line. Nitrogen, phosphorus, and calcium balances are plotted on scale, according to their ratios in normal body composition; potassium balance is not on this scale.

Long-term effects of $H G H$. After completion of the metabolic balance studies, six steroid-treated children were given prolonged courses of $\mathrm{HGH}$. Steroid dosage was maintained at a constant level, and $\mathrm{HGH}$ was administered intramuscularly 2 or 3 times a wk for $4-8$ months at a total dose of $40-120 \mathrm{mg} / \mathrm{wk}$. In contrast, the hypopituitary subjects received $10-15 \mathrm{mg}$ of $\mathrm{HGH} / \mathrm{wk}$ (in 1-2 injections). Initially, a week's supply of $\mathrm{HGH}$ was prepared at one time. Later each dose was dissolved immediately before injection. Children were seen weekly for measurement of height and weight and for observation of any untoward effects of the $\mathrm{HGH}$ or change in the pattern of their disease.

1 Unpublished observations. 
Assay of endogenous $H G H$ concentration. Fasting plasma samples obtained during the control phase of the balance studies were stored in the freezer and later analyzed for endogenous $\mathrm{HGH}$ concentration by the Glick, Roth, Yalow, and Berson radioimmunoassay (17).

\section{RESULTS}

Metabolic balance studies. Fig. 1 illustrates the results of a metabolic balance study during which HGH (preparation E-54) was administered to a child with hypopituitarism at a dose of $5 \mathrm{mg}$ /day. It can be seen that $\mathrm{HGH}$ resulted in nitrogen and potassium retention in association with marked phosphorus retention. The responses continued throughout the 12 day period of $\mathrm{HGH}$ administration and are similar to those reported in hypopituitary patients with other preparations of HGH (18-22). This study, published previously ( 7$)$, is included here for comparison with the effects observed in steroid-treated children.

Fig. 2 illustrates the response observed when the same preparation of $\mathrm{HGH}$ (E-54) was administered in doses of 10 and $20 \mathrm{mg} /$ day to an

\section{J.M. \& Age 16}

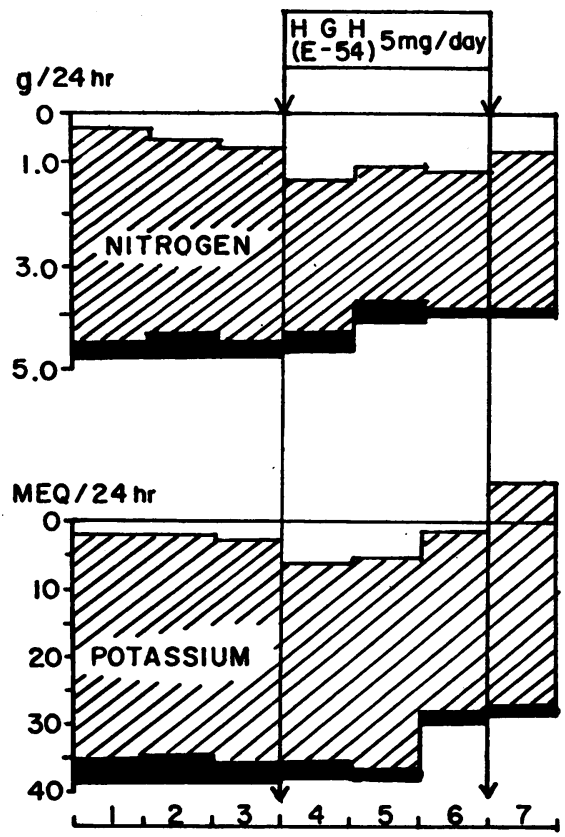

asthmatic child (P. L.) who was receiving $10 \mathrm{mg}$ of prednisone daily. Despite administration of $\mathrm{HGH}$ at 2 and 4 times the dose found to be metabolically effective in the child with hypopituitarism, the steroid-treated child showed minimal nitrogen or phosphate retention and rapid rebound excretion after termination of HGH. Detailed balance data are given in Table II A.

Fig. 3 demonstrates even less response when the same preparation of $\mathrm{HGH}(\mathrm{E}-54)$ was administered simultaneously to another asthmatic child (J. O'N.) who was receiving $20 \mathrm{mg} /$ day of prednisone. In this study (see Table II B) there was minimal response to $\mathrm{HGH}$ with return to control excretion during the short period of hormone administration. Despite a 1700 calorie diet containing $80 \mathrm{~g}$ of protein, the child was in negative metabolic balance. During a previous study, he received a higher calorie diet and maintained positive metabolic balance, but he showed a similar poor response to HGH.

Fig. 4 illustrates the response to a different

Hypopifuitarism

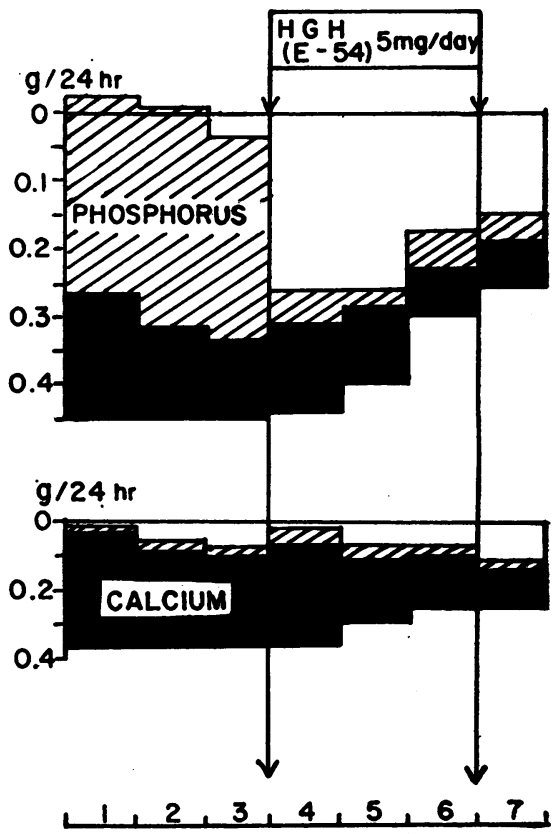

\section{Day Periods}

FigURE 1 Metabolic effects of HGH (E-54) in a hypopituitary subject. In this study, as in all balance studies to be shown, results are plotted according to the method of Reifenstein, Albright, and Wells (15). 

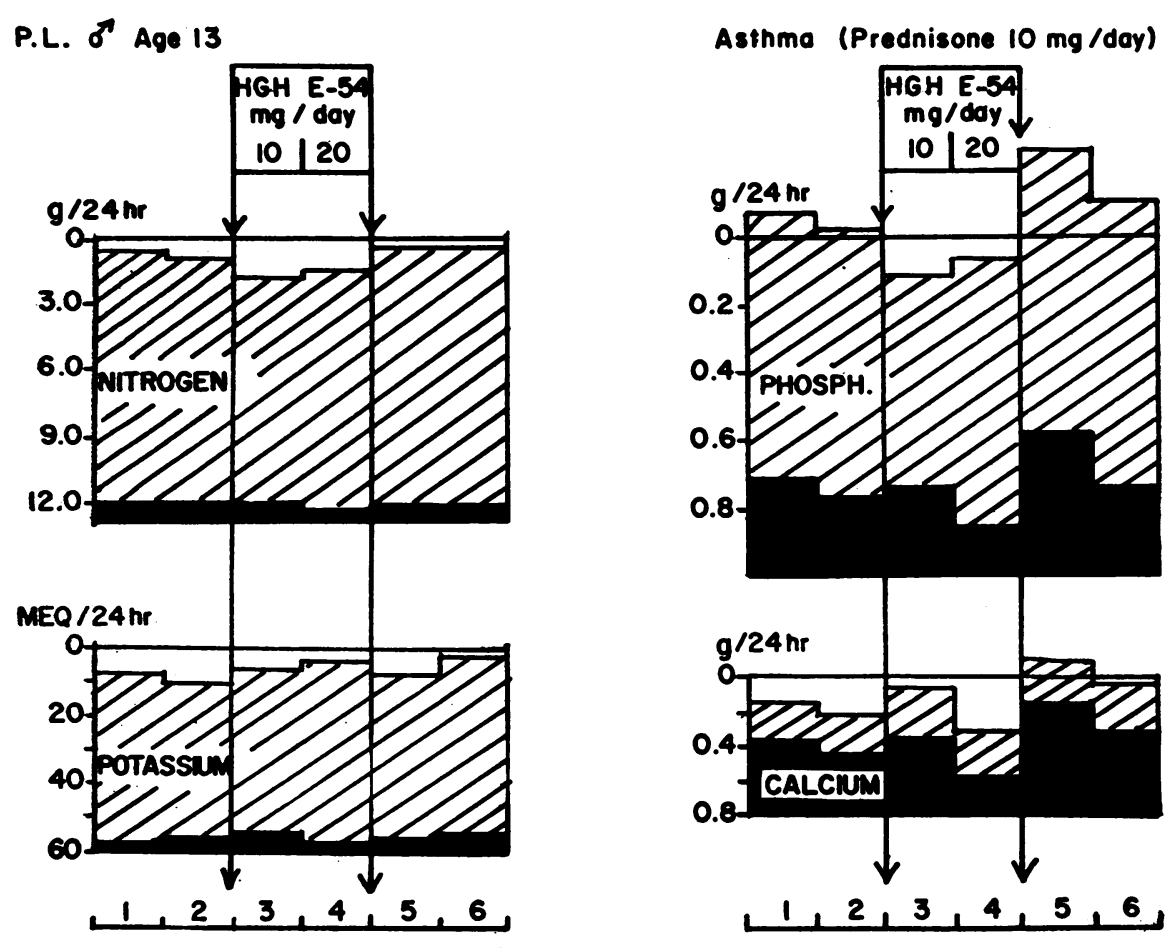

\section{Doy Periods}

FIGURE 2 Metabolic effects of HGH (E-54) in an asthmatic child receiving $10 \mathrm{mg}$ of prednisone daily. Note that because of the larger dietary intake, the scale used for plotting the balance results is different from that of Fig. 1. Analyzed phosphorus retention is slightly less than theoretic balance during the control period and equal to theoretic balance during first HGH period.

preparation of $\mathrm{HGH}$ (E2P2) when administered in doses of 10,20 , and $30 \mathrm{mg} /$ day to a child (M. K.) receiving $10 \mathrm{mg}$ of prednisone daily. The child was in positive metabolic balance during the control period. $\mathrm{HGH}$ produced an increase in nitrogen and potassium retention and in urinary calcium excretion. It can be seen, however, that the nitrogen and potassium retention were associated with paradoxical decrease in phosphorus retention, because of increase in both stool and urinary phosphorus. The negative calcium balance during $\mathrm{HGH}$ administration also resulted in part from paradoxical increase in stool excretion. The balance study carried out simultaneously in patient K. K. was similar to that shown in Fig. 4 and listed in Table II C.

The effect of steroid on calcium and phosphorus balance during $\mathrm{HGH}$ administration is further demonstrated by the responses of C. B. (Fig. 5). In the first study, shown on the left, the child was not receiving steroid and had severe asthma. This study was not entirely satisfactory because of difficulties with food intake. The second study, shown on the right, was performed several months later while the child was receiving $7.5 \mathrm{mg}$ of prednisone daily, and her asthma was well-controlled. In both studies, HGH caused retention of nitrogen and potassium but there was less retention during steroid administration. When the child was not receiving steroid, $\mathrm{HGH}$ administration resulted in phosphorus retention and growth during the course of the balance study. When she was receiving steroid, $\mathrm{HGH}$ administration resulted in decreased phosphorus retention, and growth did not occur. It can be seen from the figure that phosphorus intake was comparable during the two studies and that steroid therapy alone was associated with increased stool phosphorus. When the child was under the influence of $\mathrm{HGH}$ and steroid, there was a further marked increase in stool phosphorus and negative phosphorus balance. During steroid therapy, a similar paradoxical increase in 


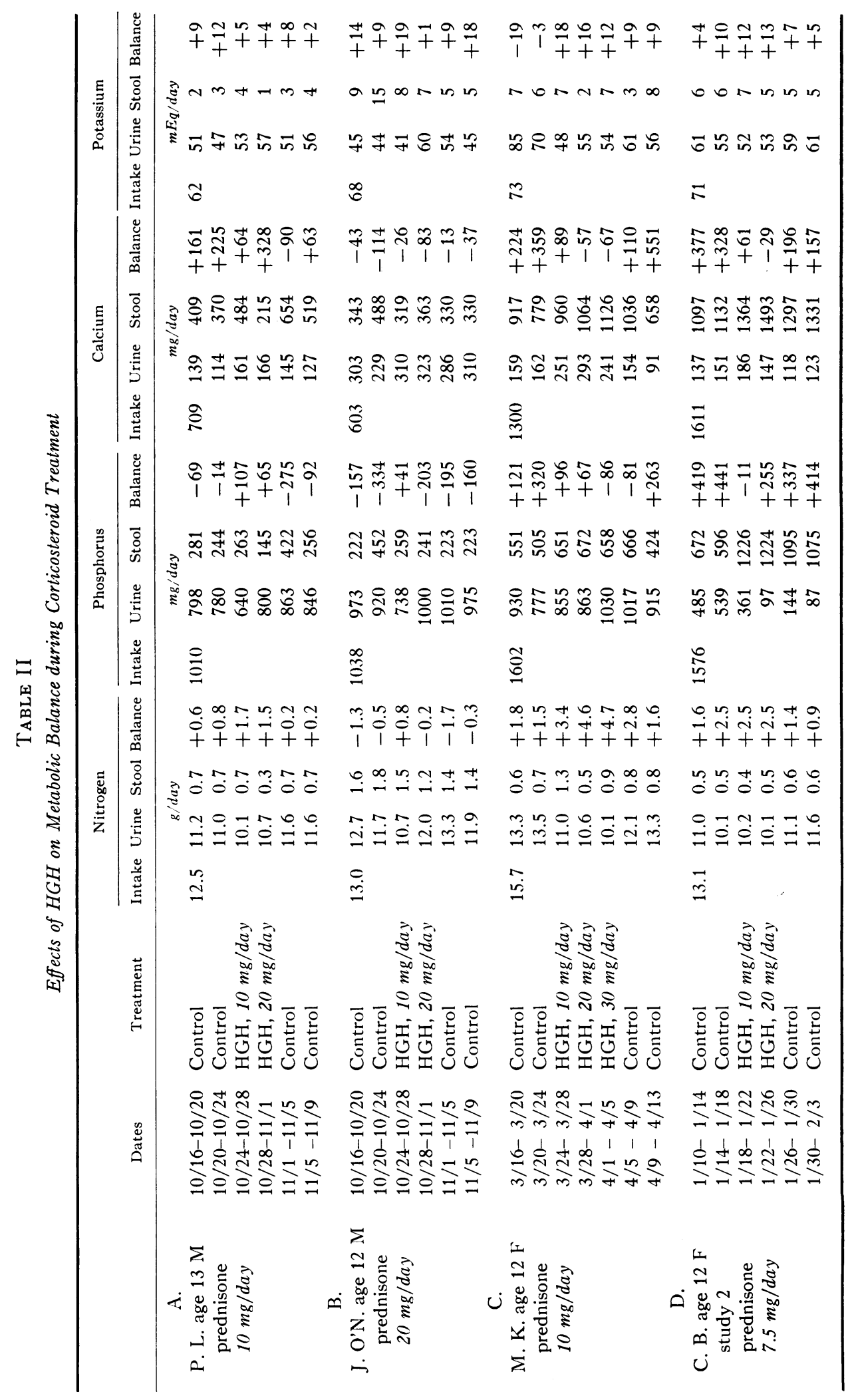




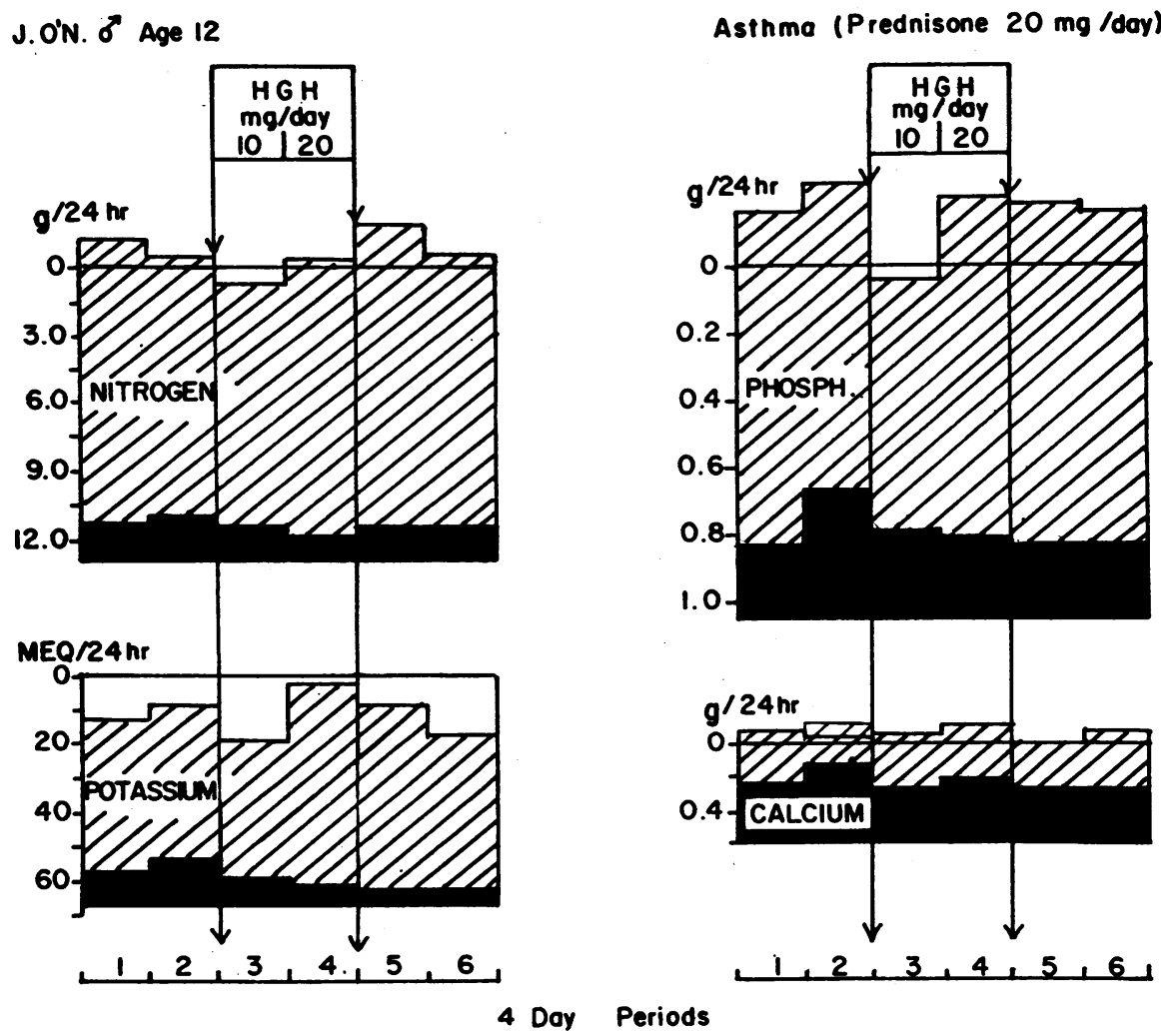

FIGURE 3 Metabolic effects of HGH (E-54) in an asthmatic child receiving $20 \mathrm{mg}$ of prednisone daily. Analyzed phosphorus balance equals theoretic balance during the control period and the HGH period.

stool calcium resulted in negative calcium balance during the $\mathrm{HGH}$ period.

The data shown in Table II and illustrated in Figs. 2-5 are representative of the results observed during each of the balance studies in the steroid-treated children. Several children showed minimal response to $\mathrm{HGH}$ by every parameter tested. Three of these subjects (P. L., J. O’N., and J. S.) were studied during two balance periods separated by an interval of several months, and they showed minimal responses on both occasions. In some of the children, (M. K., K. K., and $\mathrm{M}$. P.), $\mathrm{HGH}$ administration was associated with significant nitrogen retention, but even in these patients corresponding retention of phosphorus did not occur.

Table III lists the metabolic data obtained during $\mathrm{HGH}$ administration to two asthmatic children who were not receiving corticosteroid therapy. The markedly positive metabolic balance seen throughout study 1 of C. B. (Table III A) may be partly related to defective intake; however, excretion of nitrogen, phosphorus, and potassium showed definite decrease during $\mathrm{HGH}$ administration and reverted toward control after termination of $\mathrm{HGH}$. When the child was restudied after institution of prednisone therapy, (Table II D), HGH produced minimal change in nitrogen and potassium excretion and a marked increase in calcium and phosphorus excretion.

The responses of another nonsteroid-treated asthmatic child (E. LJ.) are shown in Fig. 6 and Table III B. In contrast to patient C. B., this patient had been symptom-free for a number of months and, except for small stature (as a result of previous corticosteroid therapy), he was essentially a normal child at the time of study. Retention of nitrogen observed during administration of $5 \mathrm{mg}$ /day of $\mathrm{HGH}$ increased further when $\mathrm{HGH}$ was increased to $10 \mathrm{mg} /$ day. Nitrogen retention was associated with slight retention of potassium and phosphorus (greatest at the $10 \mathrm{mg}$ 
dose of $\mathrm{HGH}$ ). There was no significant change in calcium balance during $\mathrm{HGH}$ administration but after withdrawal calcium balance became markedly positive.

Long-term effects of $H G H$. Despite the poor responses to $\mathrm{HGH}$ which were observed during the metabolic balance periods, six of the steroidtreated children were given large doses of $\mathrm{HGH}$ for periods of 4-8 months. Table IV lists the heights and weights of each of the children before, during, and after the period of $\mathrm{HGH}$ administration and for comparison also shows the growth record of a patient with panhypopituitarism who received the same preparations of $\mathrm{HGH}$. In contrast to the hypopituitary patient, none of the steroid-treated children showed any change in their retarded rate of growth during prolonged administration of $\mathrm{HGH}$. While the children showed no change in height or bone age, several showed significant increase in weight during $\mathrm{HGH}$ administration. This weight increase may be partly related to maintenance of corticosteroid at a constant level.

Fig. 7 graphically compares the growth response of one steroid-treated child (K. K.) with that of the hypopituitary patient (D. H.). The hypopituitary patient received $10-20 \mathrm{mg}$ of $\mathrm{HGH} / \mathrm{wk}$ and showed an increase in growth. The steroid-treated child received $\mathrm{HGH}$ for 8 months with doses of $120 \mathrm{mg} /$ wk during the last 3 months and showed minimal growth. The figure further demonstrates that the growth retardation associated with corticosteroid therapy may be even more severe than that of hypopituitarism. Thus, D. H., who had panhypopituitarism secondary to craniopharyngioma (partially resected at age 5), grew 15 inches over a period of $13 \mathrm{yr}$ with no endocrine replacement therapy. In contrast, $\mathrm{K}$. K., the steroid-treated subject, grew normally until shortly after institution of high dose corticosteroids (15 $\mathrm{mg}$ of prednisone daily), after which he showed essentially no growth.
M.K. \& Age 12

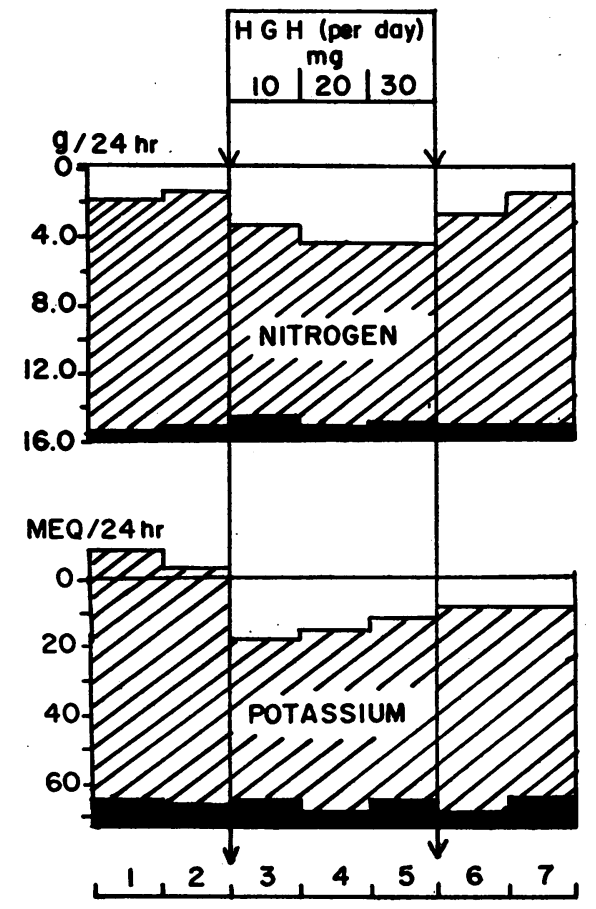

\section{Asthma (Prednisone $10 \mathrm{mg} / \mathrm{day}$ )}

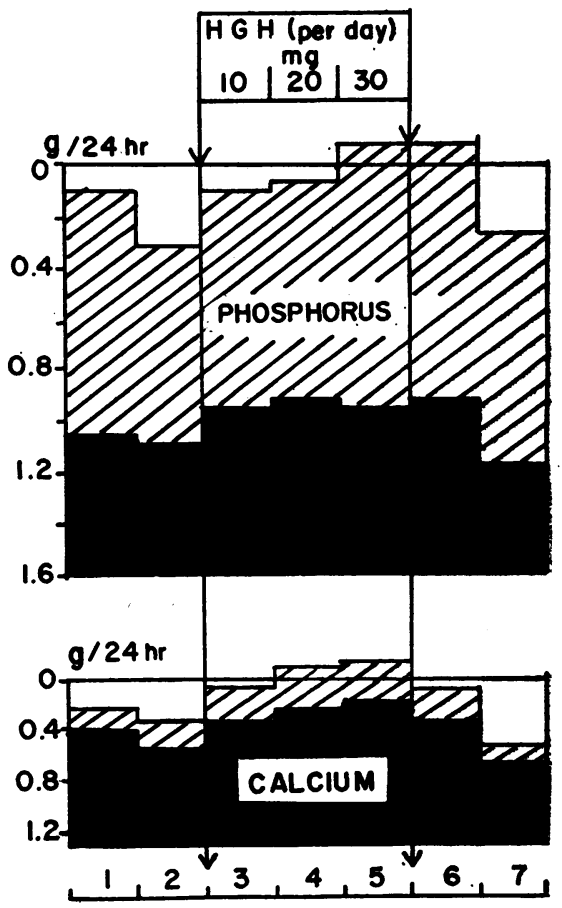

4 Day Periods

FIGURE 4 Metabolic effects of a different $\mathrm{HGH}$ preparation in an asthmatic child receiving $10 \mathrm{mg}$ of prednisone daily. Analyzed nitrogen and phosphorus balance equals theoretic balance during the control period. 

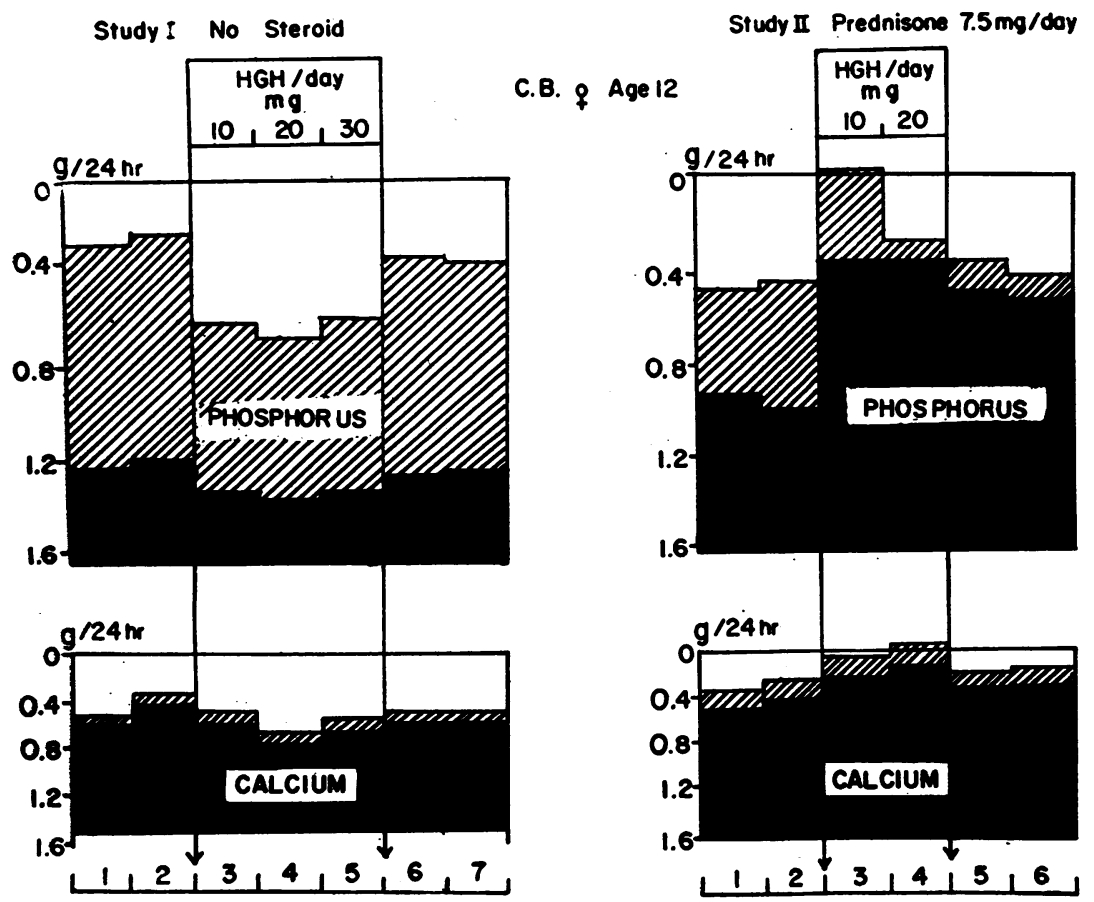

\section{Day Periods}

FIgURE 5 Comparison of the effects of HGH on phosphorus and calcium balance in an asthmatic child before and during treatment with $7.5 \mathrm{mg}$ of prednisone daily.
E. LJ. $\sigma^{\circ}$ Age 12
Elrick HGH
Asthma (No Steroids)
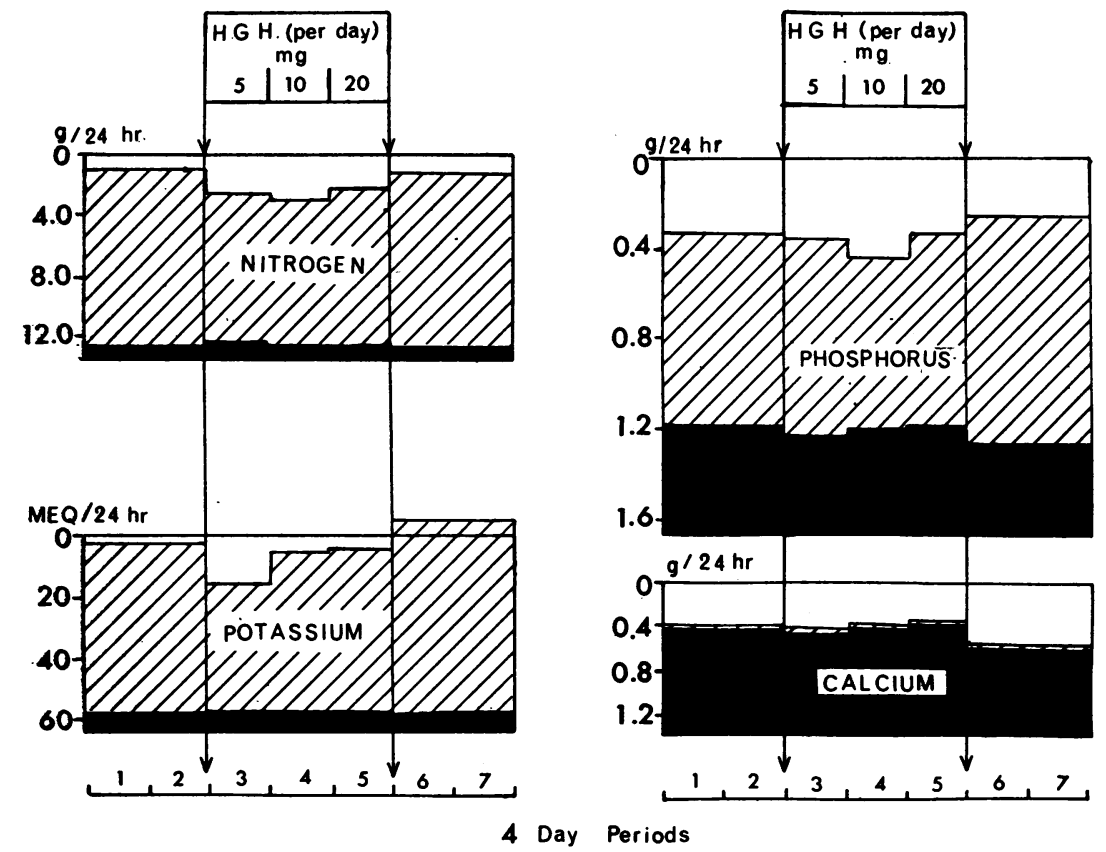

FIGURE 6 Metabolic effects of $\mathrm{HGH}$ in an asthmatic child not receiving corticosteroid therapy. 


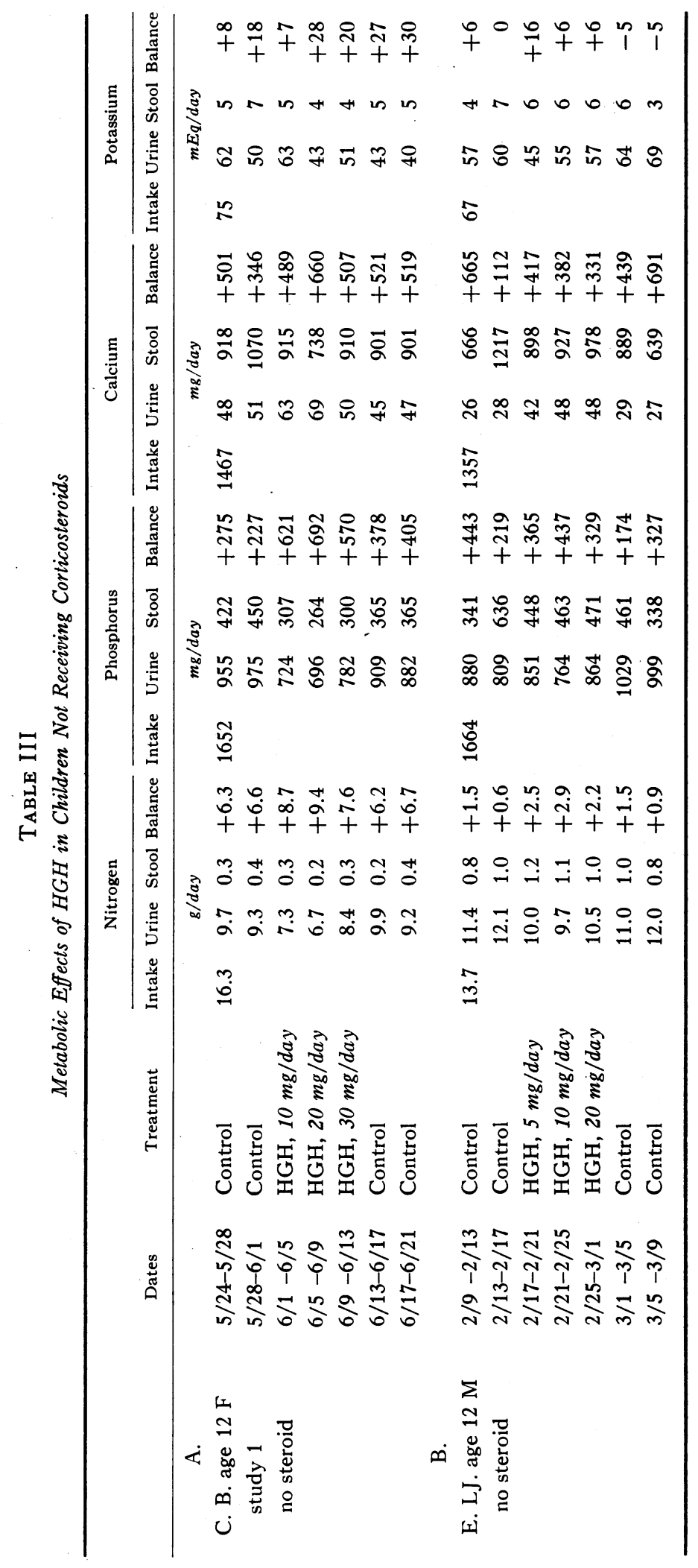


TABLE IV

Effect of Human Growth Hormone on Longitudinal Growth

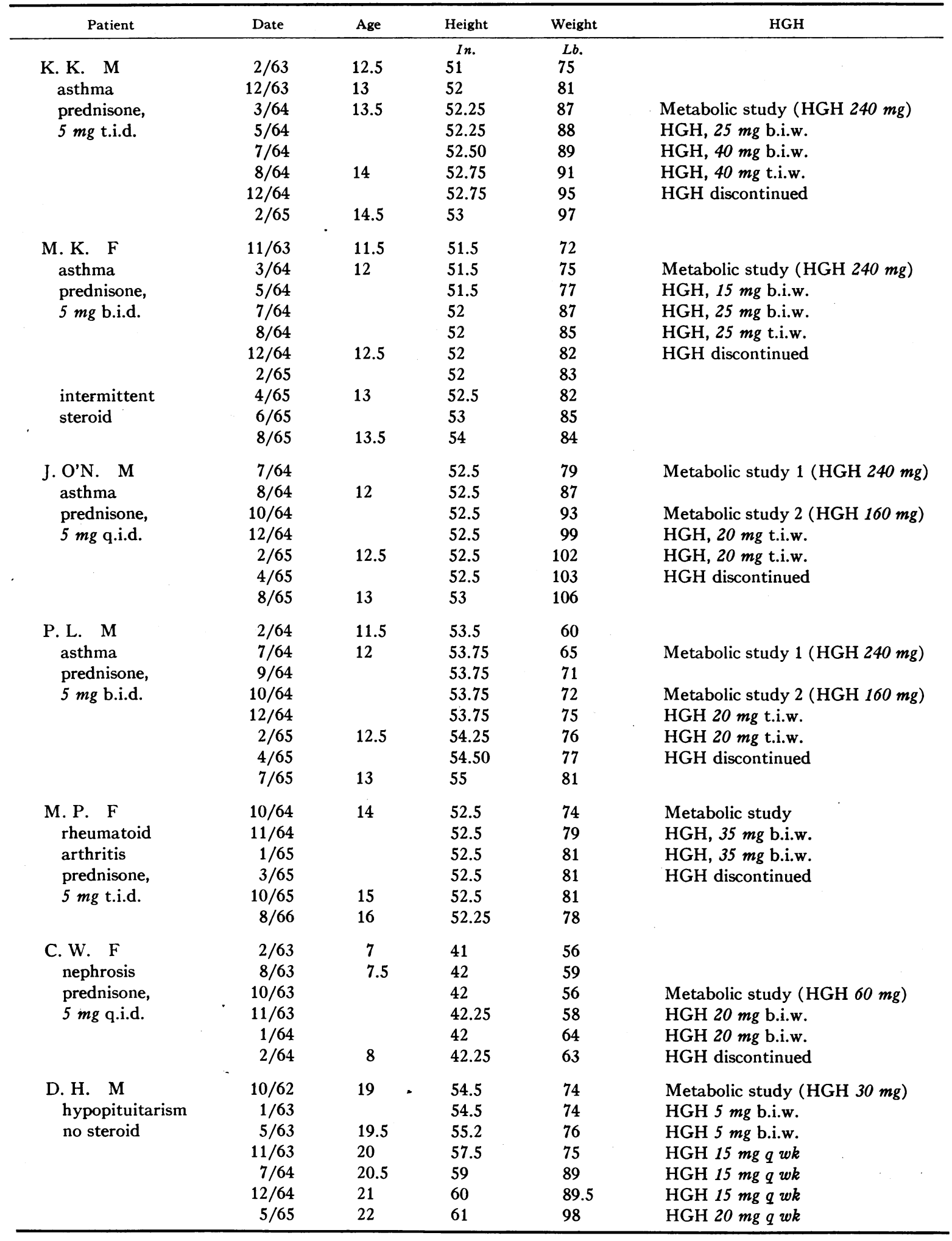




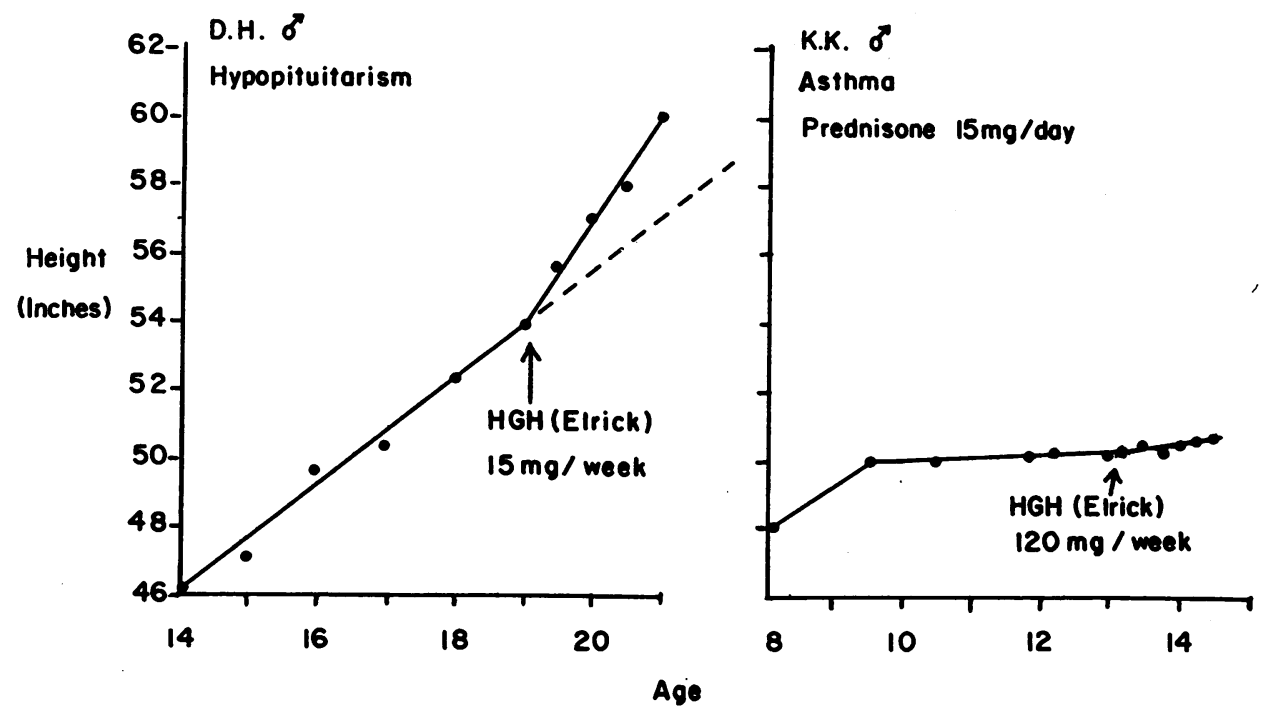

FIGURE 7 Growth response to human growth hormone. The hypopituitary subject showed acceleration of growth rate with small doses of HGH. The asthmatic child showed no improvement in his markedly retarded growth rate during treatment with large doses of $\mathrm{HGH}$.

Most of the children tolerated the HGH well. C. B. whose asthma was poorly controlled when she was not receiving corticosteroid became more symptomatic during a period of marked fluid retention while receiving $\mathrm{HGH}$. Local skin reactions characterized by redness, tenderness, and swelling occurred in $\mathrm{K}$. $\mathrm{K}$. after each injection of $\mathrm{HGH}$. A minute amount of the same $\mathrm{HGH}$ preparation injected intracutaneously produced localized blanching for 15-20 min and suggested that the local reactions were an irritant rather than an allergic phenomenon. HGH administration caused no other change in the pattern or severity of the basic disease.

Endogenous GH concentrations. The concentrations of endogenous growth hormone in fasting plasma samples obtained during control periods of the balance study are shown in the last column of Table I. It can be seen that the steroid-treated children had fasting levels of $\mathrm{GH}$ which are similar to those reported in normal preadolescent children $(23,24)$. The hypopituitary subject had unmeasurable levels of growth hormone both during fasting and after induced hypoglycemia.

\section{DISCUSSION}

The metabolic effects of $\mathrm{HGH}$ have been described by a number of investigators. Subjects have included children with hypopituitarism (22), gonadal dysgenesis $(25,26)$, constitutional dwarfism $(27,28)$, primordial dwarfism $(22,29)$, malnutrition (30), and infants $(31,32)$ and adults with a wide variety of diseases $(18-21,33)$, including Cushing's syndrome (21). In virtually all reports, the effects of small doses of $\mathrm{HGH}$ have been similar to those effects observed during the initial metabolic balance studies in 1958-60 (18-21), which demonstrated the effectiveness of $\mathrm{HGH}$ in man and showed that the response to acute administration of $\mathrm{HGH}$ is characterized by nitrogen, potassium, and phosphorus retention and increased urinary calcium excretion. The only exceptions to this response to $\mathrm{HGH}$ have been observed in children with primordial dwarfism (29). The acute metabolic responses to HGH are seen with such regularity that Wright, Brasel, Aceto, Finklestein, Kenny, Spaulding, and Blizzard (22), in reporting an extensive experience with $\mathrm{HGH}$ administration to children with various forms of dwarfism, indicated that the acute effects of administered HGH represent a pharmacologic response which is to be expected whenever an active preparation of $\mathrm{HGH}$ is administered; but acute metabolic effects, as judged by urinary excretion, are not necessarily indicative of improved growth rate during prolonged $\mathrm{HGH}$ administration.

In this study the effects of $\mathrm{HGH}$ were observed 
during 11 complete metabolic balance studies of eight children who had significant growth retardation as a result of prolonged corticosteroid therapy. Results were compared with those observed in two children with hypopituitarism and in two children with asthma who were not receiving corticosteroids. The hypopituitary patients exhibited the greatest sensitivity to $\mathrm{HGH}$ in terms of magnitude and duration of response, a finding which is in agreement with other reports. The two children who were not receiving corticosteroid demonstrated less response than the hypopituitary patients, but both showed nitrogen retention in association with phosphorus and potassium retention, and one child (C. B.) grew during the period of $\mathrm{HGH}$ administration. In contrast, the steroidtreated children had impaired response to administered growth hormone. Although large doses of HGH were given, most of the steroid-treated children showed only minimal nitrogen retention. Phosphorus balance appeared to be an even more sensitive index of anabolic response since even when nitrogen was retained, none of the steroidtreated children retained phosphorus.

Some of the abnormalities demonstrated in the steroid-treated children would have been completely overlooked had stool analysis not been performed in addition to urinary excretion studies. The paradoxical decrease in net intestinal absorption of calcium and phosphorus during $\mathrm{HGH}$ administration to the steroid-treated children emphasizes the influence of the gastrointestinal tract on metabolic balance. In contrast to previous reports which have shown that $\mathrm{HGH}$ administration increases absorption of phosphorus $(18,25)$ and calcium $(18,34)$ from the gastrointestinal tract, in several steroid-treated children increased stool excretion was largely responsible for the negative phosphorus balance and contributed to the negative calcium balance during $\mathrm{HGH}$ administration (Figs. 4 and 5).

The repeated observation of absence of phosphorus retention during administration of $\mathrm{HGH}$ to the corticosteroid-treated children is of particular interest. Corticosteroids alone are known to cause profound effects on phosphorus balance with decreased phosphorus content of muscle (35-37) and increased phosphorus excretion in urine (38$41)$ and stool $(37,41)$. HGH alone also produces significant changes in phosphorus metabolism.
While the usual effect of administered HGH during balance study has been increased retention of phosphorus in parallel with the improved nitrogen retention $(18,20,25) \mathrm{HGH}$ is known to affect phosphorus balance in the opposite direction as well. In patients with acromegaly, the bone disease presumably due to excessive $\mathrm{GH}$ has been shown to be the result of marked increase in both bone accretion and resorption rates (42). Moreover, a number of patients with active acromegaly have shown negative phosphorus balance in conjunction with the negative calcium balance (42, 43). It thus appears that the over-all effect of HGH on external phosphorus balance is the result of two opposing forces, deposition and resorption. In our study there was increased excretion of phosphorus under the influence of corticosteroids alone. The further increase in excretion under the influence of $\mathrm{HGH}$ may be the result of increased mobilization of phosphorus which is not utilizable in the presence of excess corticosteroid. The consistent finding of diminished phosphorus retention during administration of $\mathrm{HGH}$ seems significant, because it is difficult to conceive of new tissue formation occurring without phosphorus retention.

Similarly, it is impossible to conceive of new tissue formation in the absence of nitrogen retention. In many studies nitrogen has been used as the major parameter of $\mathrm{GH}$ response. However, the magnitude of the nitrogen retention often observed during administration of $\mathrm{HGH}$ is difficult to explain because it is seen in adults as well as in children (18-21) and is far in excess of the amount of nitrogen retained by normal, actively growing children (44). Furthermore, it has been shown that the nitrogen retention may not be followed by growth during long-term HGH administration (22). Recently the concept that nitrogen "retention" is adequately reflected by the difference between dietary intake and urine and stool excretion has been challenged $(45,46)$. There is evidence that urine and stool excretion may not be the only sources of nitrogen loss from the body, since excess nitrogen or ammonia is also present in expired air (46-48).

While $\mathrm{HGH}$ is of proven effectiveness in the therapy of children with growth retardation secondary to hypopituitarism (22), prolonged administration of HGH to children with other forms 
of dwarfism has yielded variable results. Some observers have reported significant improvement in growth rate during administration of $\mathrm{HGH}$ to children with gonadal dysgenesis (49) and constitutionally short stature (28), while others have reported minimal or no improvement in growth rate in children with dwarfism unrelated to pituitary disease $(27,50)$. In the present study, none of the corticosteroid-treated children demonstrated any improvement in their retarded rate of growth during prolonged therapy with large doses of $\mathrm{HGH}$.

In contrast to our studies, some investigators have reported that even small doses of HGH can overcome effects of excessive corticosteroid. Bergenstal and Lipsett described reversal of the negative nitrogen balance with $5 \mathrm{mg} /$ day of Raben growth hormone in a patient with Cushing's syndrome (21). Matiasevic and Gershberg (51) described marked improvement in growth rate during administration of $9 \mathrm{mg} / \mathrm{wk}$ of Wilhelmi HGH to two children who were receiving corticosteroid in doses similar to our patients. We have no explanation for these differences from our results.

It seems very unlikely that the responses observed in the present study are related to the specific preparations of $\mathrm{HGH}$ used (Elrick HGH). Each of the preparations was demonstrated by the rat tibia bioassay to have potent biologic activity $(5,6)$, and the hypopituitary subjects showed typical responses to $\mathrm{HGH}$ during both acute and long-term administration. It seems apparent that the altered effects observed in the steroid-treated children were related to altered ability to respond to the hormone.

Antagonism between growth hormone and corticosteroids has been suggested by reports of others. In 1952, Selye (52) demonstrated in intact rats that inhibition of linear growth during corticosteroid administration could be overcome by simultaneous administration of a crude beef growth hormone preparation and that larger amounts of growth hormone were required as steroid dosage was increased. Similar results were reported earlier with $\mathrm{ACTH}$ in intact (53) and hypophysectomized (54) rats and more recently with cortisone by Soyka and Crawford (55). Small doses of cortisone have also been shown to inhibit growth in children with hypopituitarism. Blodgett, Burgin, Iezzoni, Gribetz, and Talbot re- ported cortisone-inhibition of the retarded growth rate in untreated patients (1), while Soyka and Crawford (55) showed that the improved growth rate during $\mathrm{HGH}$ administration was inhibited by steroids but could be restored by increasing the dose of HGH. In both studies, the dosage of cortisone was lower than that which permits normal growth in children with Addison's disease (1). These observations suggest that the antagonistic effects of growth hormone and corticosteroids are dose-related. In the present study, we were unable to demonstrate any difference in response to HGH during steroid therapy at doses ranging between 7.5 and $30 \mathrm{mg} /$ day of prednisone. The deleterious effects of the steroid were not overcome by $30 \mathrm{mg} /$ day of $\mathrm{HGH}$ during the acute balance study or by dosages up to $120 \mathrm{mg}$ of $\mathrm{HGH} /$ wk during long-term studies. It is possible that during steroid therapy in the dose range encountered in this study, still larger doses of $\mathrm{HGH}$ would be required to overcome the effect of the steroid.

It has recently been reported that in adults corticosteroids inhibit pituitary release of growth hormone after hypoglycemia $(56,57)$, and it has been postulated that relative deficiency of endogenous growth hormone might in part explain the growth retardation of steroid-treated children (56). The results of the present study demonstrate that doses of $\mathrm{HGH}$ in the range of 8 times the amount shown to be growth promoting in a hypopituitary patient are ineffective in the steroidtreated children. Moreover, as indicated in Table I and as will be described further in a separate communication from this laboratory, plasma levels of endogenous $\mathrm{HGH}$, both during the fasting state and after hypoglycemia, are similar in steroidtreated and nonsteroid-treated asthmatic children (58). Our results are in agreement with the thesis that the growth retardation is related to the "anti-anabolic effect" of corticosteroids (59) and may be associated with peripheral tissue inability to respond normally to available $\mathrm{HGH}$.

Several lines of evidence indicate that deficiency of growth hormone is not the responsible mechanism for most forms of dwarfism. Most children with growth retardation have normal plasma levels of $\mathrm{GH}$ and show normal responsiveness to induced hypoglycemia $(24,60,61)$. Furthermore, such children show little or no improvement in 
growth rate during therapy with $\mathrm{HGH}(27,50)$. These data suggest that the growth retardation may result from limited capacity of peripheral tissue to respond to available $\mathrm{GH}$.

In certain forms of dwarfism such as gonadal dysgenesis and primordial dwarfism, the abnormality in responsiveness to $\mathrm{HGH}$ may be a genetic defect. In steroid-induced dwarfism, the abnormality results from the medication $(3,4)$ and is reversible if steroids can be discontinued (1). Other evidence which demonstrates the role of tissue responsiveness has been obtained in this laboratory where it has been observed that starving but otherwise normal individuals demonstrate a paradoxical response to $\mathrm{HGH}$, with increased excretion of nitrogen, phosphorus, and sodium instead of the opposite effect seen during $\mathrm{HGH}$ administration to fed subjects (62). The requirements necessary for tissue responsiveness to $\mathrm{HGH}$ are unknown. However, if the mechanisms responsible for corticosteroid-induced dwarfism can be determined, these may point the way to mechanisms responsible for other forms of dwarfism.

\section{ACKNOWLEDGMENT}

The authors gratefully acknowledge the expert dietary management provided by Miss Therese Beaudette, Head Dietitian, University of Colorado Clinical Research Center; we are also indebted to Dr. Dalton Jenkins for advice and encouragement throughout the course of this work.

This work was supported by a V.A. Clinical Investigatorship and Clinical Research Grants FR 00051 and FR 00068 from the U. S. Public Health Service. Dr. Morris is a V.A. Clinical Investigator.

\section{REFERENCES}

1. Blodgett, F. M., L. Burgin, D. Iezzoni, D. Gribetz, and N. B. Talbot. 1956. Effects of prolonged cortisone treatment on the statural growth, skeletal maturation and metabolic status of children. New Engl. J. Med. 254: 636.

2. Van Metre, T. E., Jr., and H. L. Pinkerton, Jr. 1959. Growth suppression in asthmatic children receiving prolonged therapy with prednisone and methylprednisone. J. Allergy. 30: 103.

3. Falliers, C. J., L. S. Tan, J. Szentivanyi, J. R. Jorgensen, and S. C. Bukantz. 1963. Childhood asthma and steroid therapy as influences on growth $\mathrm{Am}$. J. Diseases Children. 105: 127.

4. Falliers, C. J., J. R. Jorgensen, and S. C. Bukantz. 1963. Childhood asthma and steroid therapy. Am. J. Diseases Children. 106: 116.
5. Elrick, H., V. Yearwood-Drayton, Y. Arai, F. Leaver, and H. G. Morris. 1963. Collection, processing and fractionation of human pituitary glands. J. Clin. Endocrinol. Metab. 23: 694.

6. Elrick, H., V. Yearwood-Drayton, Y. Arai, and H. G. Morris. 1964. Hormonal content of human pituitaries from embalmed bodies. J. Clin. Endocrinol. Metab. 24: 910 .

7. Morris, H. G., C. J. Hlad, Jr., H. Elrick, and R. E. Goldsmith. 1965. Metabolic effects of human growth hormone derived from embalmed bodies. J. Clin. Endocrinol. Metab. 25: 134.

8. Hawk. P. B., I. Oser, and W. H. Summerson. 1954. Practical Physiologic Chemistry. Blakiston Div. of McGraw-Hill Book Co., Inc., York, $\mathrm{Pa}$. 13th edition. 876.

9. Walsh, A. 1955. The application of atomic absorption spectra to chemical analysis. Spectrochim. Acta. 7: 108.

10. Chen, P. S., Jr., T. Y. Toribara, and H. Warner. 1954. Microdetermination of phosphorus. Anal. Chem. 28: 1756.

11. Shannon, I. L., and J. R. Prigmore. 1960. Parotid fluid flow rate. Its relationship to $\mathrm{pH}$ and chemical composition. Oral Surg., Oral Med., and Oral Pathol. 13: 1488

12. Hawk, P. B., I Oser, and W. H. Summerson. 1951. Practical Physiologic Chemistry. Blakiston Div. of McGraw-Hill Book Co., Inc., York, $\mathrm{Pa}$. 12th edition. 506.

13. Watt, B. K., and A. L. Merrill. Composition of Foods: Raw, Processed, Prepared. 1963. United States Department of Agriculture, Washington, D. C.

14. Bowes, A. De P., and C. F. Church. 1963. Food Values of Portions Commonly Used. J. B. Lippincott Co., Philadelphia, $\mathrm{Pa}$. 9th edition.

15. Consolazio, C. F., R. E. Johnson, and L. J. Pecora. 1963. Physiologic Measurements of Metabolic Functions in Man. McGraw-Hill Book Co., Inc. New York. 313.

16. Reifenstein, E. C., Jr., F. Albright, and S. L. Wells. 1945. The accumulation, interpretation and presentation of data pertaining to metabolic balances, notably those of calcium, phosphorus, and nitrogen. J. Clin. Endocrinol. Metab. 5: 367.

17. Glick, S. M., J. Roth, R. S. Yalow, and S. A. Berson. 1963. Immunoassay of human growth hormone in plasma. Nature. 199: 784.

18. Henneman, P. H., A. P. Forbes, M. Moldawer, E. F. Dempsey, and E. L. Carroll. 1960. Effects of human growth hormone in man. J. Clin. Invest. 39: 1223.

19. Beck, J. C., E. E. McGarry, I. Dyrenfurth, and E. H. Venning. 1958. The metabolic effects of human and monkey growth hormone in man. Ann. Internal Med. 49: 1090 .

20. Ikkos, D., R. Luft, and C. A. Gemzell. 1958. Effect of human growth hormone in man. Lancet. 1: 720.

21. Bergenstal, D. M., and M. B. Lipsett. 1960. Metabolic effects of human growth hormone and growth hor- 
mone of other species in man. J. Clin. Endocrinol. Mctab. 20: 1427.

22. Wright, J. C., J. A. Brasel, T. Aceto, Jr., J. W. Finklestein, F. M. Kenny, J. S. Spaulding, and R. M. Blizzard. 1965. Studies with human growth hormone: an attempt to correlate metabolic response during short-term administration with linear growth during prolonged therapy. Am. J. Med. 38: 499.

23. Greenwood, F. C., W. M. Hunter, and V. J. Marrian. 1964. Growth hormone levels in children and adolescents. Brit. Med. J. 1: 25.

24. Kaplan, S. L., C. A. L. Abrams, J. J. Bell, F. A. Conte, and M. M. Grumbach. 1965. Serum growth hormone response to insulin-induced hypoglycemia in disorders of growth. Abstracts from 6th Pan American Congress of Endocrinology, Mexico City.

25. Forbes, A. P., J. G. Jacobsen, E. L. Carroll, and M. M. Pechet. 1962. Studies of growth arrest in gonadal dysgenesis: response to exogenous human growth hormone. Metab. Clin. Exptl. 11: 56.

26. Almqvist, S., K. Hall, S. Lindstedt, J. Lindsten, R. Luft, and H. E. Sjöberg. 1964. Effect of shortterm administration of physiological doses of human growth hormone in three patients with Turner's Syndrome. Acta Endocrinol. 46: 451.

27. Soyka, L. F., A. Ziskind, and J. D. Crawford. 1964. Treatment of short stature in children and adolescents with human pituitary growth hormone (Raben) : Experience with 35 Cases. New Engl. J. Med. 271: 754.

28. Raben, M. S., F. Matsuzake, and P. R. Mintor. 1964. Growth promoting and metabolic effects of growth hormone. Metab. Clin. Exptl. 13: 1102.

29. Lipsett, M. B., D. M. Bergenstal, and F. G. Dhyse. 1961. Metabolic studies with human growth hormone in dwarfism and acromegaly. J. Clin. Endocrinol. Metab. 21: 119.

30. Mönckeberg, F., G. Donoso, S. Oxman, N. Pak, and J. Meneghello. 1963. Human growth hormone in infant malnutrition. Pediatrics. 31: 58.

31. Ducharme, J. R., and M. M. Grumbach. 1961. Studies on the effects of human growth hormone in premature infants. J. Clin. Invest. 40: 243.

32. Vest, M., J. Girard, and U. Buhler. 1963. Metabolic effects of short-term administration of human growth hormone in infancy and early childhood. Acta Endocrinol. 44: 613 .

33. Beck, J. C., A. Gonda, M. A. Hamid, R. O. Morgen, D. Rubenstein, and E. E. McGarry. 1964. Some metabolic changes induced by primate growth hormone and purified ovine prolactin. Metab. Clin. Exptl. 13: 1108.

34. Finklestein, J. D., and D. Schachter. 1962. Active transport of calcium by intestine: effect of hypophysectomy and growth hormone. Am. J. Physiol. 203: 873 .

35. Kepler, E. J., R. G. Sprague, H. L. Mason, and M. H. Power. 1948. The pathologic physiology of adrenal cortical tumors and Cushing's syndrome. Recent Progr. Hormone Res. 2: 345.
36. Eliel, L. P., O. H. Pearson, B. Katz, and F. W. Kraintz. 1950. Comparison of lymphoid tumor and muscle electrolyte composition in patients treated with ACTH and cortisone acetate. Federation Proc. 9: 168. (Abstr.)

37. Eliel, L. P., L. Hellman, O. H. Pearson, and B. Katz. 1951. The effects of ACTH on electrolyte content of various body tissues. In Proceedings of the 2nd ACTH Conference, Chicago. 1950. J. R. Mote, editor. Blakiston Div. of McGraw-Hill Book Co., Inc., Philadelphia, Pa. 1: 196.

38. Roberts, K. E., and R. F. Pitts. 1953. The effects of cortisone and desoxycorticosterone on the renal tubular reabsorption of phosphorus and the excretion of titratable acid and potassium in dogs. Endocrinology. 52: 324 .

39. Ingbar, S. H., E. H. Kass, C. H. Burnett, A. S. Relman, B. A. Burrows, and J. H. Sisson. 1951. The effects of ACTH and cortisone on the renal tubular transport of uric acid, phosphorus, and electrolytes in patients with normal renal and adrenal function. J. Lab. Clin. Med. 38: 533.

40. Anderson, J., and J. B. Foster. 1959. The effect of cortisone on urinary phosphate excretion in man. Clin. Sci. 18: 437.

41. Sprague, R. G., M. H. Power, H. L. Mason, A. Albert, D. R. Mathieson, P. S. Hench, E. C. Kendall, C. H. Slocumb, and H. F. Polley. 1950. Observations on the physiologic effects of cortisone and ACTH in man. Arch. Internal Med. 85: 199.

42. Bell, N. H., and F. C. Bartter. 1967. Studies of ${ }^{47} \mathrm{Ca}$ metabolism in acromegaly. J. Clin. Endocrinol. Metab. 27: 178.

43. Albright, F., and E. C. Reifenstein, Jr. 1948. The parathyroid glands and metabolic bone disease. The Williams \& Wilkins Co., Baltimore, Md. 188.

44. Macy, I. G. 1942. Nutrition and Chemical Growth in Childhood. Charles C Thomas, Springfield. 1: 153.

45. Costa, G. 1960. Hypothetical pathway of nitrogen metabolism. Nature. 188: 549.

46. Costa, G., L. Ullrich, F. Kantor, and J. F. Holland. 1965. Conversion of protein nitrogen into $\mathrm{N}_{2}$ by certain mammals including man. Clin. Res. 13: 320. (Abstr.)

47. Robin, E. D., D. M. Travis, P. A. Bromberg, C. E. Forkner, Jr., and J. M. Tyler 1959. Ammonia excretion by mammalian lung. Science. 129: 270.

48. Jacquez, J. A., J. W. Poppell, and R. Jeltsch. 1959. Partial pressure of ammonia in alveolar air. Science. 129: 269.

49. Ferrier, P., S. Gartler, C. P. Mahoney, T. H. Shepard, II, and B. Burt. 1961. Study of a case of gonadal dysgenesis with positive chromatin pattern. Am. J. Diseases Children. 102: 581 (Abstr.)

50. Mason, A. S., and J. M. Tanner. 1967. Human growth hormone in the treatment of dwarfism. In Modern Trends in Endocrinology. H. Gardner-Hill, editor. Butterworth \& Co. Ltd., London. p. 1. 
51. Matiasevic, D., and H. Gershberg. 1966. Studies on hydroxyproline excretion and corticosteroid induced dwarfism. Metab. Clin. Exptl. 15: 720.

52. Selye, H. 1952. Prevention of cortisone overdosage effect with somatotrophic hormone (STH). Am. J. Physiol. 171: 381.

53. Becks, H., M. E. Simpson, C. H. Li, and H. M. Evans. 1944. Effects of adrenocorticotrophic hormone (ACTH) on the osseus system of normal rats. Endocrinology. 34: 305.

54. Becks, H., M. E. Simpson, W. Marx, C. H. Li, and H. M. Evans. 1944. Antagonism of pituitary adrenocorticotropic hormone (ACTH) to the action of growth hormone on the osseous system of hypophysectomized rats. Endocrinology. $34: 311$.

55. Soyka, L. F., and J. D. Crawford. 1965. Antagonism by cortisone of the linear growth induced in hypopituitary patients and hypophysectomized rats by human growth hormone. J. Clin. Endocrinol. Metab. $25: 469$.

56. Frantz A. G., and M. T. Rabkin. 1964. Human growth hormone, clinical measurement, response to hypoglycemia and suppression by corticosteroids. Nezw Engl. J. Med. 271: 1375.
57. Hartog, M., M. A. Gaafer, and R. Fraser. 1964. Effect of corticosteroids on serum growth hormone. Lancet. 2: 376 .

58. Morris, H. G., J. R. Jorgensen, and S. A. Jenkins. 1968. Plasma growth hormone concentrations in corticosteroid-treated children. J. Clin. Invest. $47: 427$.

59. Albright, F. 1943. Harvey Lectures. Cushing's syndrome. Its pathological physiology, its relationship to the adreno-genital syndrome, and its connection with the problem of the reaction of the body to injurious agents ("Alarm Reaction" of Selye). Science Press Printing Co., Lancaster. 38: 123.

60. Root, A. W., R. L. Rosenfield, A. M. Bongiovanni, and W. R. Eberlein. 1967. The plasma growth hormone response to insulin-induced hypoglycemia in children with retardation of growth. Pediatrics. 39: 844.

61. Stimmler, L., and G. A. Brown. 1967. Growth hormone secretion provoked by insulin-induced hypoglycemia in children of short stature. Arch. Disease Childhood. 42: 232.

62. Drenick, E., H. G. Morris, and H. Elrick. 1965. Effects of human growth hormone during starvation. Progrem of the 47th meeting of the Endocrine Society, New York. (Abstr.) 